\title{
Tercerização segundo Maquiavel
}

\author{
Valter R. de Carvalho \\ Graduado em Economia e Administração; Mestre em Administração - Mackenzie; \\ Professor e Coordenador de Estágio Curricular do Curso de Administração da \\ UNINOVE.
}

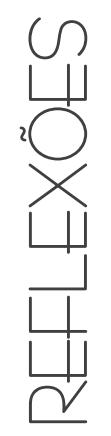

0 princííio da terceirização já existia mesmo em tempos bem remotos. Na Roma antiga, senhores nobres e grandes latifundiários constituíam os próprios exércitos para prote-gerem os seus patrimônios. Também os reis, príncipes eimperadores seutilizavam desse expediente para a proteção das polis, as cidades-Estado do período. Cada cidade, portanto, mantinha um exército para garantia da segurança do governante e da soberania do território.

Além das organizações formais, criadas pelo próprio Estado, havia grandes guerreiros ou mesmo 'especuladores', que arregimentavam homens e os treinavam para se tornarem soldados com habilidades e conhecimentos de guerra, formando, assim, verdadeiros exércitos privados. Eram chamados por Maquiavel de exércitos mercenários, disponíveis para contratação por reis, príncipes, imperadores e outros nobres que necessitassem dos seus serviços de proteção patrimonial e territorial, ou para invasão de outras terras, fato que acontecia quase sempre em casos de emergência. Os comandantes dessas legiões não passavam de prestadores de serviços de segurança, tanto de Cidades-Estado quanto de pessoas físicas que, por motivos óbvios, deles necessitassem.

Isso se tornou prática constante, pois era de menor custo para os contratantes, uma vez que não precisavam arcar com despesas de alimentação, cuidados médicos e treinamento, muito caros à época. Com o tempo, essa prática foi caindo em desuso em razão da quebra de fidelidade, porque os contratados estabeleciam compromisso maior com quem pagasse melhor, e os contratantes deixam de confiar neles. Muitas vezes, 0 exército contratado levava à derrota os próprios 'clientes', já que o que se buscava era melhor paga, conforme relata Maquiavel.

0 autor de 0 Príncipe (1513/1514) relata que 0 Estado - novo, antigo ou misto - tem sua base principal no exército com o qual o príncipe defende o seu território, que pode ser próprio, mercenário, auxiliar ou misto. Destaca que os exércitos mercenário e auxiliar (pertencentes a outro Estado) são inúteis e perigosos e, quando os príncipes confiam sua segurança aos mercenários, ficam à mercê destes, pois a desunião, indisciplina, falta de lealdade e ambição levam 0 Estado à insegurança, tornando-o vulnerável ao inimigo. Grandes impérios caíram por terem contratado esses exércitos; conseqüentemente, as maiores vitórias se deveram aos combates efetuados por exércitos próprios, isto é, compostos de cidadãos que eram homens comprometidos com o seu próprio Estado.

Outros exemplos de terceirização ocorreram no período da segunda grande guerra mundial, quando as indústrias norte-americanas estavam voltadas para a fabricação de armas. Houve, portanto, a necessidade de transferir para outras indústrias a fabricação de peças e componentes, em virtude de estarem com sua capacidade de produção esgotada (GIOSA, 1997). Tratava-se de uma nova prática de prestação de serviç̧os, pela qual as empresas delegavam a outras parte das suas atividades, a fim de atenderem as demandas existentes.

0 mundo hoje está consolidando, cada vez mais e em todos os níveis da economia, a prática da prestação de serviços executada por terceiros, tanto no setor privado quanto no público.

Para o SINDEPRESTEM - Sindicato das Empresas de Prestação de Serviços a Terceiros, a terceirização é um processo por meio do qual a empresa transfere algumas atividades para outras, estabelecendo uma parceria, mantendo as atividades principais do negócio. A terceirização se integra às estratégias das organizações, não se distanciando do ambiente e da cultura delas. Utiliza- 
se do know-how e das orientações fornecidas pelos contratantes dos serviços, e é vista também como um instrumento de redução de custos.

No Brasil, a terceirização começou no setor de serviços de limpeza, alimentação, vigilância, treinamento de mão-de-obra, transporte, assistência médica, publicidade e propaganda. Dado o sucesso alcançado, vem atuando nos mais diversos setores empresariais e governamentais, explorando as atividades-meio, enquanto as atividades-fim ficam sob a responsabilidade dos contratantes.

MARTINS (2000) e GIOSA (1997) são unânimes quando definem a terceirização como sendo a transferência, para terceiros, das atividades que não fazem parte do negócio principal das organizações. Tanto esta quanto outras definições permitem concluir que essa modalidade muito antiga de prestação de serviços continua crescendo e ocupa um lugar de grande importância para os setores produtivos - industrial, financeiro ou de serviços, diferenciando-se das práticas da sua origem, pois as atividades-fim dos que contratam continuam sob seu controle.

\section{Considerações finais}

Observa-se, portanto, que a prestação de serviços como a terceirização, é praticada desde os tempos mais antigos. Hoje tem sido utilizada em larga escala nos diversos segmentos da sociedade, consolidando o seu caráter de parceria e sendo responsável por grande parte de emprego de mão-de-obra nas economias nacional e globalizada.
É prudente, contudo, fazer-se uma reflexão sobre 0 uso desta modalidade de prestação de serviços, uma vez que as empresas confiam a terceiros apenas as atividades secundárias, ficando com 0 controle absoluto das principais. Com base nisso, é recomendável que se faça uma analogia entre as práticas atuais e as verificadas naquela época, para corroborar a importância e os interesses que envolvem esse tipo de trabalho.

Pela análise que se fez da prática da terceirização através do tempo, respeitando-se os interesses e necessidades de sua utilização, conclui-se que a prestação de serviços por terceiros é um processo antigo que recebeu inovações técnico-administrativas substanciais que garantiram sua permanência, como elemento indispensável, nas economias globalizadas de hoje.

\section{Referências bibliográficas}

BINI, Edson. Maquiavel: o príncipe. Comentários de Napoleão Bonaparte. São Paulo: Hemus, 1996.

CARTILHA SOBRE TERCEIRIZAÇÃO. SINDEPRESTEM - Sindicado das E mpresas de P restação de Serviços a Terceiros, Colocação de Administração de M ão-de-obra e de Trabalho no Estado de São Paulo, s/d.

CLARET, Martin. 0 pensamento vivo de Maquiavel. São Paulo: Martins Claret ,1992.

GIOSA, Livio A. Terceirização: uma abordagem estratégica. São Paulo: Pioneira, 1997.

MARTINS, Sergio P. A terceirização e 0 direito do trabalho. São Paulo: Atlas, 2000. 